\title{
Hubungan Antara Employee Engagement Dan Kepuasan Kerja Dengan Kinerja
}

\author{
Dhea Dana Mariska \\ Magister Profesi Psikolog, Fakultas Psikologi, \\ Universitas Tujuh Belas Agustus 1945 Surabaya \\ danamariska@gmail.com
}

\begin{abstract}
Abstrak
Kinerja merupakan suatu hasil perilaku karyawan untuk menjalankan pekerjaan sesuai dengan kompetensi. Hasil perilaku karyawan saat mengerjakan pekerjaan merupakan keterikatan karyawan terhadap organisasi yang di dukung dengan kepuasan saat bekerja. Penelitian ini dilakukan pada karyawan PT K. Jumlah subjek penelitian adalah 100 orang. Seluruh subjek bekerja minimal 1 tahun dengan pendidikan minimal DIII dan rentang usia 20-50 tahun. Hipotesis diuji dengan analisis regresi. Hasilnya menunjukkan ada hubungan yang signifikan antara employee engagement dan kepuasan kerja dengan kinerja $(\mathrm{F}=30.622 ; \mathrm{R}=$ 0.387). Employee engagement mempunyai hubungan yang signifikan dengan kinerja $(\mathrm{r}=0.536 ; \mathrm{p}=0.00)$, dan kepuasan kerja yang mempunyai hubungan yang signifikan dengan kinerja $(\mathrm{r}=0.448 ; \mathrm{p}=0.00)$. Hasil penelitian menunjukkan bahwa ada hubungan employee engagement dan kepuasan kerja dengan kinerja.
\end{abstract}

Kata Kunci: employee engagement; kepuasan kerja; kinerja

\section{Pendahuluan}

Pekerjaan di dalam organisasi perlu koordinasi yang baik antara pimpinan dan bawahannya di dalam perusahaan. Suatu pekerjaan dapat dikerjakan dengan baik apabila karyawan dalam keadaan yang baik dan situasi lingkungan kerja yang baik pula sehingga karyawan mampu menghasilkan output yang optimal sesuai dengan tugas yang diberikan dalam bekerja. Hasil kerja yang tinggi maupun yang rendah karyawan sangat berpengaruh pada perusahaan.

Adanya perilaku kerja tinggi ataupun rendah disebabkan beberapa aspek aspek seperti kuantitas dan kuallitas kerja, kemampuan, inisiatif, ketepatan waktu komunikasi di lingkungan kerja. Selain itu faktor pengaruh kinerja karyawan adalah sosial, psikologis dan individu yang dirasakan oleh karyawan. Kinerja karyawan menurut Donnelly, Gibson dan Ivancevich (Rivai, 2005) kinerja 
merujuk kepada tingkat keberhasilan dalam melaksanakan tugas serta kemampuan untuk mencapai tujuan yang telah ditetapkan.

Sikap karyawan terhadap tugasnya mencerminkan pengalaman yang menyenangkan atau rasa puas dan pengalaman yang tidak menyenangkan atau rasa tidak puas. Menurut Locke (2005) mendefinisikan kepuasan sebagai tidak ada selisihnya antara kondisi yang diinginkan dengan kondisi aktual. Salah satu pengaruh kinerja karyawan adalah kepuasan kerja. Kepuasan dalam bekerja menentukan tingkat hasil kerja kinerja yang tinggi dan rendah.

Adanya kepuasan kerja diharapkan dapat mengoptimalkan kinerja karyawan dalam memperoleh hasil yang baik. Kepuasan Kerja adalah suatu tingkatan perasaan yang baik atau buruk tentang beberapa aspek dari pekerjaan, situasi kerja, dan hubungan dengan teman kerja (Schermerhorm, 1985). Selain kepuasan kerja, faktor pengaruh hasil kerja karyawan adalah employee engagement.

Employee engagement memiliki kaitan lain dalam perilaku organisasi. Gagasan dalam perilaku organisasi ini berbicara tentang hubungan karyawan dengan organisasi. Sebagai salah satu gagasan dalam perilaku organisasi, employee engagement berbeda dengan gagasan lain seperti komitmen organisasi. Berdasarkan uraian diatas penulis meneliti hubungan employee engagement dan kepuasan kerja terhadap kinerja, maka penulis memilih judul yang berkaitan dengan hal-hal tersebut diatas, yaitu " Hubungan Employee engagement dan Kepuasan Kerja dengan Kinerja Karyawan”.

\section{Metode}

Variabel bebas pada penelitian ini adalah Employee engagement dan Kepuasan kerja.Menurut ahli Thomas (2009) (dalam Akbar, 2013) employee engagement yang diartikan sebagai suatu tingkatan bagi seseorang yang secara aktif memiliki managemen pribadi sendiri dalam mengerjakan pekerjaan. Dimensi employee engagement menurut Thomas (2007), yaitu : (a) kesiapan, (b) kerelaan, (c) kebanggaan. Kepuasan kerja menurut Robbins (2008) dapat dilihat validitasnya dengan menggunakan lima indikator yaitu Pertama adalah kepuasan dengan pembayaran hasil kerja, yaitu upah yang didapatkan seseorang sebanding 
dengan usaha yang dilakukan dan sama dengan upah yang diterima oleh orang lain dalam posisi kerja yang sama.Kedua adalah kepuasan dengan tugas/pekerjaan itu sendiri, yaitu sejauh mana pekerjaan menyediakan kesempatan seseorang untuk belajar memperoleh tanggung jawab dalam suatu tugas tertentu dan tantangan untuk pekerjaan yang menarik. Ketiga adalah kepuasan dengan promosi, yaitu kesempatan seseorang untuk meraih atau dipromosikan ke jenjang yang lebih tinggi dalam organisasi.

Keempat yaitu kepuasan dengan sikap atasan, yaitu kemampuan atasan untuk memberikan bantuan tehnis dan dukungan terhadap pekerjaan yang menjadi tanggung jawab para bawahan.Kelima adalah kepuasan dengan rekan kerja, yaitu sejauh mana rekan kerja secara teknis cakap dan secara sosial mendukung tugas rekan kerja lainnya.

Variabel terikat pada penelitian ini adalah Kinerja.Bangun (2012) menyatakan bahwa untuk memberi kemudahan penilaian kinerja karyawan, standar pekerjaan harus dapat diukur dan dipahami. Suatu pekerjaan dapat dilihat kevaliditasnya melalui 5 dimensi, yaitu a. Kuantitas pekerjaan; hal ini menunjukkan jumlah pekerjaan yang dihasilkan sendiri atau berkelompok sebagai suatu syarat yang menjadi sebuah standar pekerjaan, b. Kualitas pekerjaan;setiap karyawan dalam perusahaan harus memenuhi persyaratan tertentu untuk dapat menghasilkan pekerjaan sesuai kualitas yang dituntut suatu pekerjaan tertentu, c. ketepatan waktu; setiap pekerjaan memiliki karakeristik, namun untuk jenis pekerjaan tertentu harus diselesaikan tepat waktu, karena memiliki ketergantungan dalam pekerjaan lainnya, d. Kehadiran; suatu jenis pekerjaan tertentu menuntut kehadiran karyawan dalam mengerjakannya sesuai waktu yang ditentukan, dan e. Kemampuan kerja samatidak semua pekerjaan dapat diselesaikan oleh satu karyawan saja, untuk berbagai pekerjaan tertentu mungkin harus diselesaikan oleh dua orang karyawan atau lebih. Kinerja karyawan dapat dinilai dari kemampuannya bekerja sama dengan rekan sekerja lainnya.

Subjek pada penelitian ini adalah karyawan PT K yang memiliki masa kerja minimal 1 tahun dengan tingkat pendidikan minimal DIII.Rentang usia mulai 20 50 tahun. Cara yang digunakan untuk mengambil sampel dalam penelitian ini 
dengan cara purposive random sampling.Sampel yang akan diambil disesuaikan dengan karakteristik atau ciri-ciri yang akan digunakan menjadi subjek. Dalam penelitian ini jumlah subjek penelitian yang digunakan sebanyak 100 orang. Penelitian ini menggunakan pendekatan kuantitatif.

Pendekatan kuantitatif adalah penelitian yang banyak menggunakan angkaangka, mulai dari pengumpulan data, penafsiran terhadap data serta penampilan dari hasilnya (Arikunto, S, 2006).

\section{Hasil dan Pembahasan}

Terhadap hipotesis ada hubungan antara employee engagement dan kepuasan kerja dengan kinerja karyawan, berdasarkan hasil analisis data membuktikan bahwa ada hubungan antara employee engagement dan kepuasan kerja dengan kinerja karyawan.

Terhadap hipotesis ada hubungan antara employee engagement dengan kinerja karyawan, berdasarkan hasil analisis data Koefisien korelasi antara employee engagement dengan kinerja karyawan adalah 0,536 dengan $\mathrm{p}=0,00$, yang berarti hubungan kedua variabel adalah signifikan. Berdasarkan data tersebut bahwa ada hubungan antara employee engagement dengan kinerja karyawan.

Terhadap hipotesis ada hubungan antara kepuasan kerjadengan kinerja karyawan, berdasarkan hasil analisis data Koefisien korelasi antara kepuasan kerja dengan kinerja karyawan adalah 0,448 dengan $p=0,00$, yang berarti hubungan kedua variabel adalah signifikan. Berdasarkan data tersebut bahwa ada hubungan antara kepuasan kerja dengan kinerja karyawan.

Data yang diperoleh dianalisis dan menunjukkan nilai korelasi ganda $\mathrm{R}$ sebesar 0,387 dan nilai $\mathrm{F}=30,622$; dengan $\mathrm{p}=0,000$. Nilai $\mathrm{p}<0,05$. Berdasarkan analisis statistika bahwa ada hubungan antara employee engagement dan kepuasan kerja dengan kinerja karyawan.

Penelitian ini dilakukan terhadap 100 karyawan PT K. Pada penelitian ini hipotesis pertama yang menyatakan ada hubungan antara employee engagement dan kepuasan kerja dengan kinerja karyawan terbukti secara empiris dengan nilai korelasi ganda $\mathrm{R}$ sebesar 0,387 dan nilai $\mathrm{F}=30,622$; dengan $\mathrm{p}=0,000$. Nilai $\mathrm{p}<$ 
0,05. Menunjukan bahwa employee engagement dan kepuasan kerja dengan kinerja memiliki hubungan.

Hal ini didukung dengan faktor yang mempengaruhi kinerja yaitu individu dan stimulasi. Individu terdiri dari pengalaman bekerja, pendidikan, jenis kelamin, umur, motivasi, kondisi fisik dan kepribadian. Selain itu faktor situasional terdiri dari faktor sosial dan organisasi melalui kebijakan perusahaan, jenis latihan, pengalaman, sistem upah serta lingkungan sosial.

Selain itu faktor fisik pekerjaan dan pekerjaan meliputi metode kerja, pengaturan dan kondisi kerja serta perlengkapan kerja (Suharto \& Cahyono, 2005). Dari beberapa faktor penelitian ini mewakili kinerja yang memiliki hubungan employee engagement dan kepuasan kerja. Hipotesis selanjutnya menyatakan bahwa ada hubungan antara employee engagement dengan kinerja karyawan terbukti dengan nilai koefisien korelasi sebesar 0,536 dengan $p=0,00$. Koefisien korelasi tersebut menunjukan semakin tinggi employee engagement maka semakin tinggi pula kinerja karyawan.

Seperti yang diungkapkan oleh Mangkunegara (2001) bahwa kinerja sebagai hasil kerja secara kualitas dan kuantitas yang dicapai oleh seorang pegawai melaksanakan tugasnya sesuai tanggung jawab yang diberikan kepadanya. Dalam pencapaian hasil kerja secara kualitas dan kuantitas terdapat keterikatan karyawan meliputi karyawan memahami peran dan tanggung jawab pekerjaan, banyaknya antusias untuk bekerja dan pada perusahaan serta bersedia berkontribusi berusaha dan bekerja sesuai dengan pekerjaannya (Novianto, 2012).

Hipotesis ketiga adalah ada hubungan antara kepuasan kerja dengan kinerja karyawan terbukti dengan nilai koefisien korelasi sebesar 0, 448 dengan $p=0,00$. Koefisien korelasi tersebut menunjukan bahwa tinggi kepuasan kerja maka tinggi pula kinerja karyawan. Sesuai yang pendapat disampaikan oleh Handoko (Tangkilisan, 2005) kepuasan kerja sebagai penilaian atau cerminan dari perasaan kerja terhadap pekerjaannya.

Hal ini terlihat sikap pekerja terhadap pekerjaannya. Terdapat sedikit perbedaan antara nilai koefisien korelasi antara employee engagement dan kepuasan kerja, dimana lebih tinggi employee engagement dibanding kepuasan 
kerja. Berdasarkan hasil tersebut dapat dikatakan bahwa employee engagement memiliki hubungan yang lebih kuat dibandingkan kepuasan kerja. Apabila terdapat pilihan mana yang ditingkatkan terlebih dahulu antara meningkatkan employee engagement atau kepuasan kerja untuk meningkatkan kinerja, maka yang memilki potensi paling cepat meningkatkan kinerja ialah dengan meningkatkan employee engagement. Hasil analisis regresi dengan variabel employee engagement dan kepuasan kerja sebagai prediktor dan variabel kinerja sebagai kriterium mempunyai hubungan yang signifikan.

Penelitian ini membuktikan kaitan antara employee engagement dan kepuasan kerja terhadap kinerja karyawan. Mengingat begitu banyak variasi dari variabel yang diteliti, maka perlu ada penelitian lebih lanjut mengenai peranan dari setiap aspek maupun dengan melibatkan variabel lain yang dapat memberikan sumbangan terbesar pada kinerja.

\section{Kesimpulan dan Saran}

\section{Kesimpulan}

Penelitian ini dilakukan pada karyawan di PT K. Jumlah subjek penelitian ini adalah 100 orang. Seluruh subjek bekerja di PT K minimal 1 tahun dengan status karyawan diperbantukan, karyawan tetap dan karyawan pkwt dan memiliki tingkat pendidikan minimal DIII dengan usia mulai 20 - 50 tahun. Analisis data menggunakan teknik regresi. Hasilnya menunjukkan peran yang signifikan dari variabel employee engagement dan kepuasan kerja dengan kinerja karyawan.

\section{Saran}

Untuk perusahaan mengingat hasil penelitian menunjukkan adanya hubungan antara employee engagement dan kepuasan kerja dengan kinerja karyawan, maka instansi perlu memperhatikan masalah employee engagement dan kepuasan kerja yang saat ini berlaku.

Bentuk yang diwujudkan dapat berupa upaya untuk membangun suasana kerja yang nyaman dan kebijakan yang berdampak positif bagi kinerja karyawan, kebijakan tersebut seperti mengadakan gathering karyawan. Untuk karyawan diupayakan untuk membangun ruang lingkup kerjanya menjadi nyaman, menjalin 
hubungan yang baik dengan rekan kerja dan peduli terhadap pekerjaanya sehingga memiliki perasaan senang untuk membuatnya lebih bersemangat dalam bekerja sehingga dapat meningkatkan kinerjanya.

\section{DAFTAR PUSTAKA}

Engkko, Cecilia. 2008. Pengaruh Kepuasan Kerja Terhadap Kinerja Individual Dengan Self Esteem Sebagai Variabel Intervening. Ambon. Jurnal Bisnis dan Akuntansi

Fenia, Selvi Zola. 2015. Perana Employee engagementTerhadap Peningkatan Kinerja. Padang. Jurnal Ekobistek Fakultas Ekonomi, Vol. 4, No. 2

Handayani, Fitria. 2016. Hubungan Antara Kepuasan Kerja dan Kinerja Karyawan Bagian Produksi PT. X di Pasuruan. Surabaya. Jurnal Ilmiah Mahasiswa Universitas Surabaya Vol. 5. No 1

Hilmi, Indah L. 2013. Peran Employee engagement sebagai mediasi budaya organisais karyawan instalasi rumah sakit. Bandung. Jurnal Farmasi Klinik Indonesia, Vol. 2

Indrawati, Ayu Desi. 2013. Pengaruh kepuasan kerja terhadap kinerja karyawan dan kepuasan pelanggan pada rumah sakit swasta di kota denpasar. Denpasar. Jurnal Manajemen, Strategi Bisnis dan Kewirausahaan Vol. 7 No 2.

Juniantara, I Wayan. 2015. Pengaruh Motivasi dan Kepuasan Kerja Terhadap Kinerja Karyawan Koperasi di Denpasar. Denpasar. E-Jurnal Ekonomi dan Bisnis Universitas Udayana 4.09

Nusatria, Sandi. 2012. Employee engagement : Anteseden dan Konsekuensi. Semarang. Jurnal Online

Rachmatullah, Aditia. 2015. Pengaruh Motivasi Kerja Terhadap Employee engagement. Bandung. E-procedding Of Management: Vol. 2 No. 3.

Rachmawati, Meida. 2013. Employee engagement sebagai kunci meningkatkan kinerja karyawan. Salatiga. Jurnal Among Makanti Vol. 6 No 12

Rahmah, Siti. 2013. Hubungan Gaya Kepimpinan Transformasional Dengan Employee engagement Karyawan PT PLN Area Samarinda. Samarinda. Ejournal Psikologi, Vol. 1 No. 2 
Ratnawati, Intan. 2012. Analisis Pengaruh Budaya Organisasi dan Kepuasan Kerja Terhadap Komitmen Organisasional Dalam Meningkatkan Kinerja Karyawan. Semarang. Jurnal Bisnis dan Ekonomi Vol. 19, No. 2

Robbins, S.P. 2006. Perilaku Organisasi, terjemahan Benyamin Molan. Jakarta. PT Indeks.

Sungkit, Flavia Norpina. 2015. Pengaruh Job Enrichment terhadap Employee engagement melalui Pschological Meaningfulness sebagai mediator. Jogjakarta. Gadjah Mada Journal Of Psychology Vol. 1 No. 1

Widodo, Fransiscus. 2013. Hubungan Employee engagement dengan perilaku produktif karyawan. Surabaya. Jurnal Psikologi Industri dan Organisasi Vol. 2 No. 1.

Yanidrawati, Kartika. 2012. Hubungan Kepuasan Kerja Dengan Kinerja Perawat Di Ruang Rawat Inap Rumah Sakit Umum Daerah Kabupaten Bekasi. Bekasi. Jurnal Ilmu Keperawatan Universitas Padjajaran. 